\title{
Effects of anion complexation on the photoreactivity of bisureido- and bisthioureido-substituted dibenzobarrelene derivatives
}

Heiko Ihmels* and Jia Luo

\author{
Full Research Paper \\ Address: \\ Organic Chemistry II, University of Siegen, Adolf-Reichwein-Str. 2, \\ D-57068 Siegen, Germany \\ Email: \\ Heiko Ihmels* - inmels@chemie.uni-siegen.de \\ * Corresponding author \\ Keywords: \\ dibenzobarrelenes; dibenzosemibullvalenes; di-m-methane \\ rearrangement; supramolecular photochemistry; (thio)urea derivatives
}

Open Access

\author{
Beilstein J. Org. Chem. 2011, 7, 278-289. \\ doi:10.3762/bjoc. 7.37 \\ Received: 11 November 2010 \\ Accepted: 04 February 2011 \\ Published: 04 March 2011 \\ This article is part of the Thematic Series "Photocycloaddition and \\ photorearrangement". \\ Guest Editor: A. G. Griesbeck \\ (C) 2011 Ihmels and Luo; licensee Beilstein-Institut. \\ License and terms: see end of document.
}

\begin{abstract}
Bisureido- and a bisthioureido-substituted dibenzobarrelene derivative were synthesized and the photoreactivity of two representative examples were studied. Direct irradiation of the ureido-substituted derivative induces a di- $\pi$-methane rearrangement to the corresponding dibenzosemibullvalene derivative, whereas the thioureido-substituted derivative is almost photoinert. Complexes of the latter derivative with chloride, carboxylates, or sulfonate anions, however, are efficiently transformed to the dibenzosemibullvalene product upon irradiation, presumably by suppressing the self-quenching of the thiourea units in the complex. The association of the ureido-substituted dibenzobarrelene derivative with $(S)$-mandelate and irradiation of this complex led to the formation of the dibenzosemibullvalene with moderate stereoselectivity (68:32 er). In contrast, the thioureido derivative showed no such effect upon complexation of chiral anions.
\end{abstract}

\section{Introduction}

The control of the selectivity of a photoreaction by supramolecular interactions has recently received much attention [1-3]. For example, chiral receptors have been employed that associate with photoreactive substrates, leading to a distinct preferential conformation of the latter and/or to a limited exposure of the substrate to other reagents due to the shielding effect of the receptor. Because of the restricted freedom of movement or availability of reactive sites within this assembly, mono- and bimolecular photoreactions may proceed through one preferential pathway resulting in regio- or stereoselective product formation. Indeed, this approach has been employed to carry out stereoselective photoreactions, for example [2+2] cycloaddition [4], [4 + 4] photocycloaddition [5], Norrish-Yang

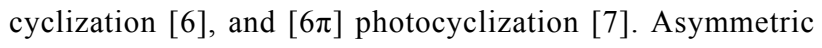
photoreactions have also been carried out with very good stereoselectivities in organized or constrained media [8-10]. For 
example, photoactive substrates may be accommodated as guest molecules in chiral host systems, such as suitably modified cucurbiturils [11-15], self-assembled cages [16] and bowls [17], liquid crystals [18], chiral crystals [19-23], or cyclodextrins (CDs) [24-26] in such a way that the chiral environment within the binding site has an influence on preferential reaction pathways, thus inducing stereoselective photoreactions.

Along these lines, the di- $\pi$-methane (DPM) rearrangement $[27,28]$ of dibenzobarrelene (dibenzobicyclo[2.2.2]octatriene) (1a) and its derivatives has been shown to be an appropriate model reaction for the assessment of substituent effects on the selectivity of organic photoreactions (Scheme 1) [29,30]. The photoreactivity of dibenzobarrelene derivatives is multiplicitydependent: The direct irradiation of 1a leads to the dibenzocyclooctatetraene $\mathbf{3 a}$ in a singlet reaction that occurs via an initial $[2+2]$ cycloaddition followed by a [4+2] retro-Diels-Alder reaction [27-30]. In the presence of a triplet sensitizer, e.g., acetone or benzophenone, a triplet-state di- $\pi$-methane rearrangement is induced. Thus, in the initial reaction step connection between one vinyl and one benzo carbon atom takes place, i.e., a so called vinyl-benzo bridging, that leads to the intermediate biradical BR1a [29]. Subsequent rearomatization with the formation of the intermediate BR2a and intramolecular radical recombination gives the dibenzosemibullvalene $\mathbf{2 a}$ as the reaction product. Notably, the DPM rearrangement of dibenzobarrelene derivatives such as $\mathbf{1 b}$, that carry substituents other than hydrogen atoms at the vinyl positions, leads to the formation of two enantiomeric dibenzosemibullvalenes $\mathbf{2} \mathbf{b}$ and ent-2b. As indicated in Scheme 1, the two enantiomers originate from different vinyl-benzo bridging pathways in the first reaction step (path a or b). Note that the same two enantiomers are formed upon initial vinyl-benzo bridging with the other benzene unit.

Stereoselective DPM rearrangements of dibenzobarrelene derivatives have been reported in special media, such as chiral mesoporous silica [31] or ionic-liquids [32]; however, most examples for stereoselective DPM rearrangements of dibenzobarrelene derivatives have been observed in the solid-state. For example, the achiral derivative $\mathbf{1 b}$ crystallizes in the chiral space group $P 2{ }_{1} 2_{1} 2_{1}$, and irradiation of the chiral crystals gives dibenzosemibullvalene $\mathbf{2 b}$ with a high enantiomeric excess, $>95 \%$ ee [33]. Since achiral molecules crystallize only very rarely in chiral space groups, the ionic chiral auxiliary strategy was developed by Scheffer et al. which allows to influence the stereoselectivity of solid-state photoreactions by chiral counter ions [34]. This is accomplished by providing the chromophore

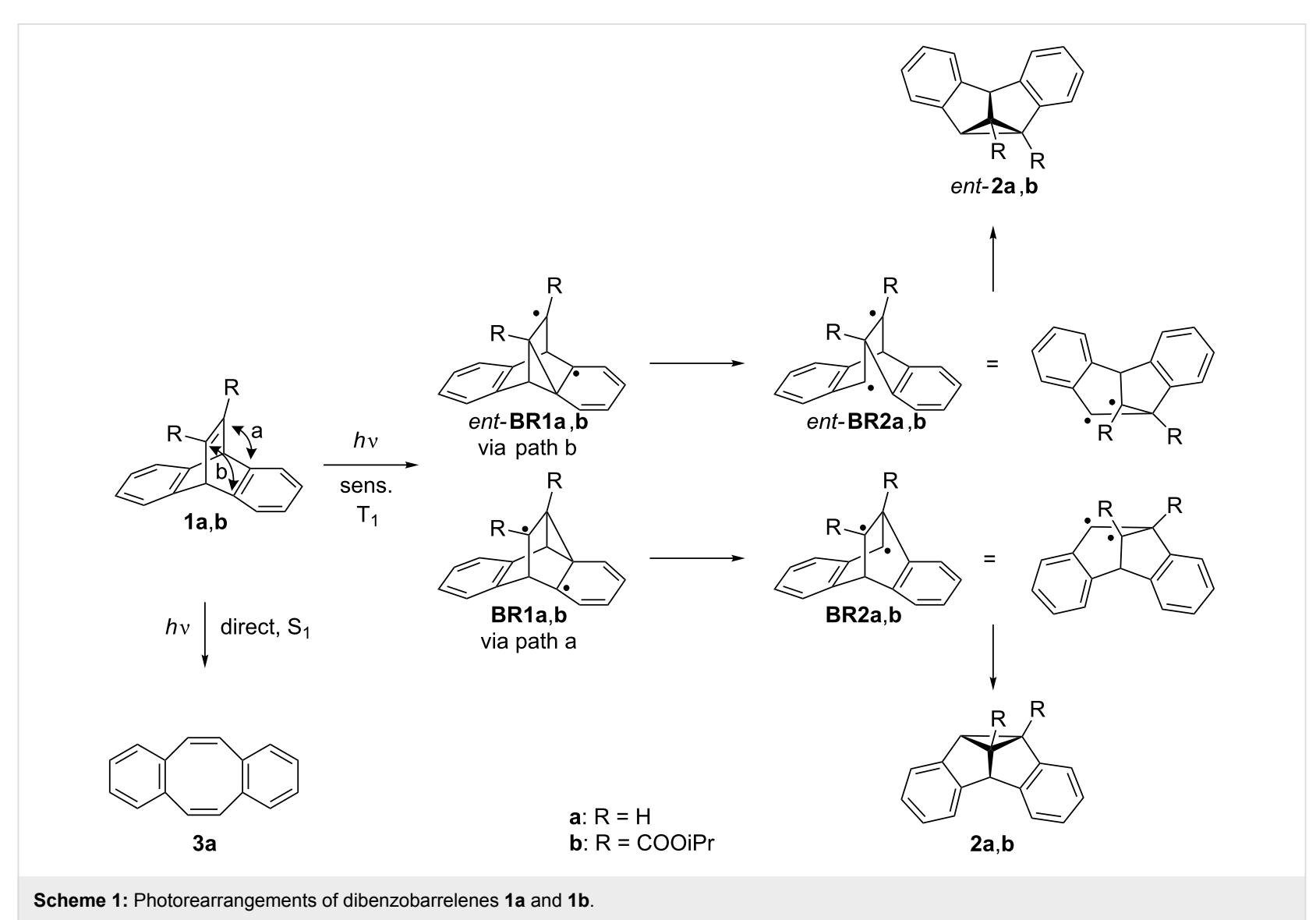



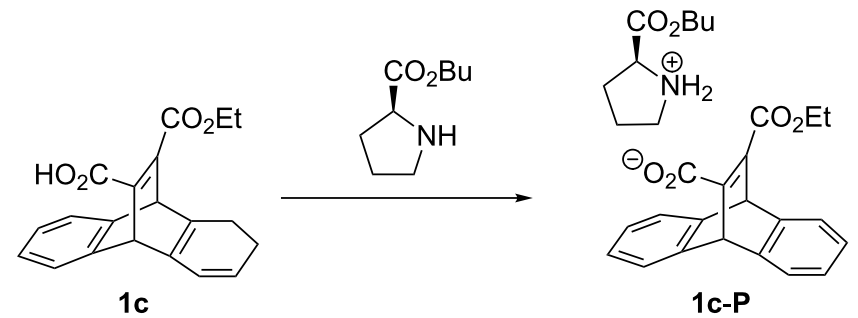

\begin{tabular}{l} 
1. $h v$, solid state \\
2. $\mathrm{H}_{3} \mathrm{O}^{+}$ \\
3. $\mathrm{CH}_{2} \mathrm{~N}_{2}$ \\
\hline
\end{tabular}

1c

1c-P

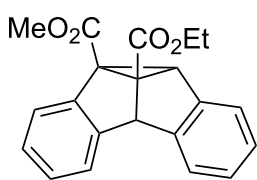

2c

Scheme 2: Stereoselective DPM rearrangement of chiral salts in the solid-state.

under investigation with a carboxylic acid functionality and then by attaching a chiral, enantiomerically pure amine by salt formation. An optically active salt is obtained, which consequently crystallizes in a chiral space group. The irradiation of these salts in the solid-state leads to enantiomerically enriched photoproducts. This approach has been successfully applied to the carboxy-substituted dibenzobarrelene derivative 1c which forms the chiral ammonium carboxylate 1c-P with $(S)$-proline (Scheme 2). After irradiation, acidic workup and subsequent esterification with diazomethane, the dibenzosemibullvalene $\mathbf{2 c}$ was obtained with high enantiomeric excess $(>95 \%$ ee) $[35,36]$

Interestingly, several asymmetric photoreactions have been conducted with remarkable enantioselectivity in homogeneous solution, whereas reports of asymmetric di- $\pi$-methane rearrangements in solutions are relatively rare. Chiral auxiliaries attached as ester or amide functionalities at the vinylic positions of dibenzobarrelene induce only low enantioselectivities in the DPM rearrangement in solution [37]; and the ionic auxiliary strategy, which generates impressive enantioselectivity in the solid-state, fails to induce any stereoselectivity in DPM rearrangements in solution. Considering these observations, it remains a challenge to develop a method to accomplish stereoselective DPM rearrangements of dibenzobarrelene derivatives in homogenous solutions. Therefore, we intended to study whether supramolecular interactions of chiral additives with achiral dibenzobarrelenes may be used to influence the photoreactivity of the latter in solution. For that purpose the dibenzobarrelene chromophore was functionalized with ureido or thioureido substituents, since these functionalities are strong hydrogen bonding donors, which may associate with (chiral) anions [38,39]. Moreover, the versatile use of urea and thiourea derivatives in organocatalysis has been demonstrated in several examples [40-44]. Herein, we report the synthesis of ureido- and thioureido-substituted dibenzobarrelene derivatives 1e-i, along with first studies of their photochemical properties in the absence and in the presence of anions.

\section{Results}

The bisureido- and bisthioureido-substituted dibenzobarrelene derivatives $\mathbf{1} \mathbf{e}-\mathbf{i}$ were synthesized by the reaction of the known bis(diaminomethyl)-substituted derivative of dibenzobarrelene 1d [45] with a slight excess of the corresponding isocyanate or isothiocyanate (Scheme 3 ). The resulting products precipitated
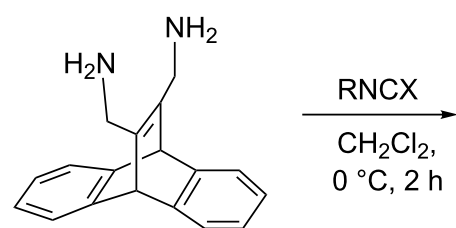

$1 d$

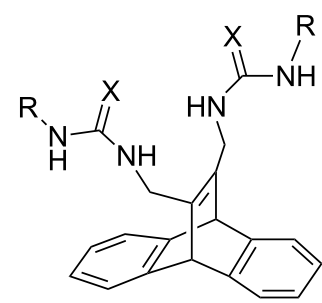

$\begin{array}{ll}\text { 1e }: \mathrm{R}=n \text { - } \mathrm{Bu}, & \mathrm{X}=\mathrm{O}(79 \%) \\ \text { 1f }: \mathrm{R}=\mathrm{Ph}, & \mathrm{X}=\mathrm{O}(72 \%) \\ \text { 1g: } \mathrm{R}=4-n \text {-butylphenyl, } \mathrm{X}=\mathrm{O}(76 \%) \\ \text { 1h: } \mathrm{R}=3,5-\left(\mathrm{CF}_{3}\right)_{2} \mathrm{C}_{6} \mathrm{H}_{3}, \mathrm{X}=\mathrm{O}(82 \%) \\ 1 \text { i }: \mathrm{R}=3,5-\left(\mathrm{CF}_{3}\right)_{2} \mathrm{C}_{6} \mathrm{H}_{3}, \mathrm{X}=\mathrm{S}(86 \%)\end{array}$ 
from the reaction mixture and were isolated in good yields (72-86\%) by direct filtration, except for the thioureido-substituted derivative 1i, which was crystallized from ethyl acetate to give crystals containing one molecule of ethyl acetate as indicated by ${ }^{1} \mathrm{H}$ NMR spectroscopy and elemental analysis. All products were fully characterized by ${ }^{1} \mathrm{H}$ and ${ }^{13} \mathrm{C}$ NMR spectroscopy, mass spectrometry, and elemental analysis. The solubility of the dibenzobarrelene derivatives $\mathbf{1 e}-\mathbf{g}$ is very low in most organic solvents (e.g., $<5 \mathrm{mg} / \mathrm{l}$ in acetonitrile at $20^{\circ} \mathrm{C}$ ). In contrast, the 3,5-bis(trifluoromethyl)phenyl-substituted derivatives $\mathbf{1 h}$ and $\mathbf{1 i}$ have significantly improved solubility in organic solvents; i.e., compound $\mathbf{1 h}$ has good solubility in acetone, acetonitrile and alcohols, while thiourea $\mathbf{1 i}$ dissolves in most polar organic solvents.

Because of their favorable solubility in organic solvents, the dibenzobarrelene derivatives $\mathbf{1 h}$ and $\mathbf{1 i}$ were used for the systematic photochemical studies. In both acetone and acetonitrile, irradiation of the bisureido-substituted derivative $\mathbf{1 h}$ gave the dibenzosemibullvalene $\mathbf{2 h}$ as the major photoproduct (Scheme 4). After irradiation of dibenzobarrelene $\mathbf{1 h}$ in acetone solution, product $2 \mathrm{~h}$ was isolated in $60 \%$ yield by crystallization directly from the reaction mixture. The structural assignment of $\mathbf{2 h}$ was based on the characteristic ${ }^{1} \mathrm{H}$ NMR shifts of the two singlets for the protons at $\mathrm{C} 8 b(3.22 \mathrm{ppm})$ and $\mathrm{C} 4 b$ (4.63 ppm). Irradiation of compound $\mathbf{1 h}$ through a quartz filter $(\lambda>254 \mathrm{~nm})$ resulted in rapid conversion of $\mathbf{1 h}$. The photolysate contained ca. $60 \%$ of $\mathbf{2 h}$, as determined by ${ }^{1} \mathrm{H}$ NMR spectroscopic analysis. The byproducts could not be identified. In contrast, no byproducts were formed when the irradiation was carried out through Duran glass $(\lambda>310 \mathrm{~nm})$; however, in this case a longer irradiation time was required . For example, after irradiation of a solution of $1 \mathbf{h}$ in acetonitrile $\left(10^{-3} \mathrm{M}\right)$ through Duran glass for $8 \mathrm{~h}$, TLC analysis still indicated the presence of the starting material, whereas in acetone solution full conversion was observed after $3 \mathrm{~h}$ irradiation under otherwise identical conditions. The reaction was significantly faster in the presence of anions: The irradiation of a solution of $\mathbf{1 h}$ and two molar equiv of tetrabutylammonium chloride (TBAC) in acetonitrile for $3 \mathrm{~h}\left(10^{-3} \mathrm{M}, \lambda>310 \mathrm{~nm}\right)$ led to complete conversion, and the semibullvalene $\mathbf{2 h}$ was obtained in $84 \%$ yield after column chromatography. Similar results were obtained in the presence of carboxylate or sulfonate salts.

The irradiation of the bisthioureido-substituted dibenzobarrelene derivative $1 \mathbf{i}$ in various organic solvents did not induce the DPM rearrangement, even in acetone, as indicated by TLC and ${ }^{1} \mathrm{H}$ NMR spectroscopic analysis of the reaction mixture. Instead, ${ }^{1} \mathrm{H}$ NMR spectroscopic analysis revealed slow decomposition of the dibenzobarrelene derivative 1i upon irradiation with no formation of distinct photoproducts. In contrast, the irradiation of compound $\mathbf{1 i}$ in the presence of 2 molar equiv of either tetrabutylammonium chloride (TBAC) or tetrabutylammonium $(S)$-camphor-10-sulfonate (SCS) in acetonitrile for 4-6 h converted the dibenzobarrelene $1 \mathrm{i}$ into the dibenzosemibullvalene $\mathbf{2} \mathbf{i}$ (Scheme 4), as indicated by the characteristic singlets of the dibenzosemibullvalene structure in the ${ }^{1} \mathrm{H}$ NMR spectrum ( $8 b-\mathrm{H}: 3.43 \mathrm{ppm}$; $4 b-\mathrm{H}: 4.76 \mathrm{ppm}$, in acetone). The dibenzosemibullvalene $2 \mathbf{i}$ was obtained in $52 \%$ yield by filtration through a column of silica gel and subsequent crystallization. The dibenzosemibullvalenes $\mathbf{2 h}$ and $\mathbf{2 i}$ were identified and fully characterized by ${ }^{1} \mathrm{H}$ NMR and ${ }^{13} \mathrm{C}$ NMR spectroscopy, elemental analysis and/or mass spectrometry.

To assess whether the influence of the anions on the photoreactivity of the dibenzobarellenes is caused by complex formation, the propensity of the urea and thiourea functionalities to associate with anions was investigated by spectrophotometric titrations of selected tetrabutylammonium salts with derivatives $\mathbf{1 h}$ and $\mathbf{1 i}$ (Figure 1). Upon the addition of TBAC, a slight change of the absorption bands of the urea derivative $\mathbf{1 h}$ was observed with the exception of the absorption maxima at
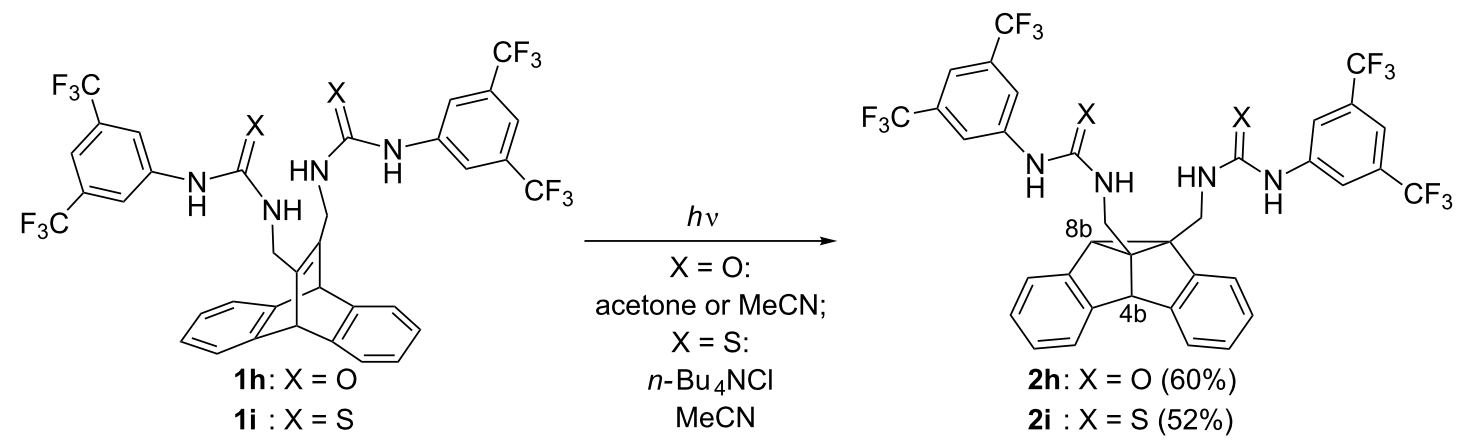

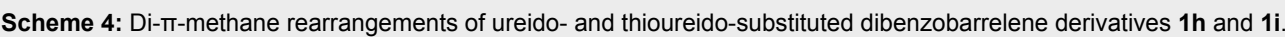


$280 \mathrm{~nm}$ which remained essentially unaffected during the titration. The latter absorption band was assigned to the dibenzobarrelene unit, by comparison with the absorption of the resembling dibenzobarrelene derivative 1d [45]. This observation indicates that the complexation of the chloride anion has no significant influence on the dibenzobarrelene chromophore, but rather on the trifluoromethyl-substituted phenyl substituents. The absorption of the thioureido-substituted derivative $\mathbf{1 i}$ changed significantly upon the addition of the sulfonate salt SCS. Specifically, the absorption maximum at $272 \mathrm{~nm}$ was red shifted by ca. $15 \mathrm{~nm}$, along with an overall increase of the absorption. In addition, an isosbestic point at $248 \mathrm{~nm}$ was observed during the titration process, which indicates an equilibrium between two different absorbing species, i.e., the free and complexed ligand. Because of the predominant absorption of the arylthiourea unit, it was not possible to assess the influ-
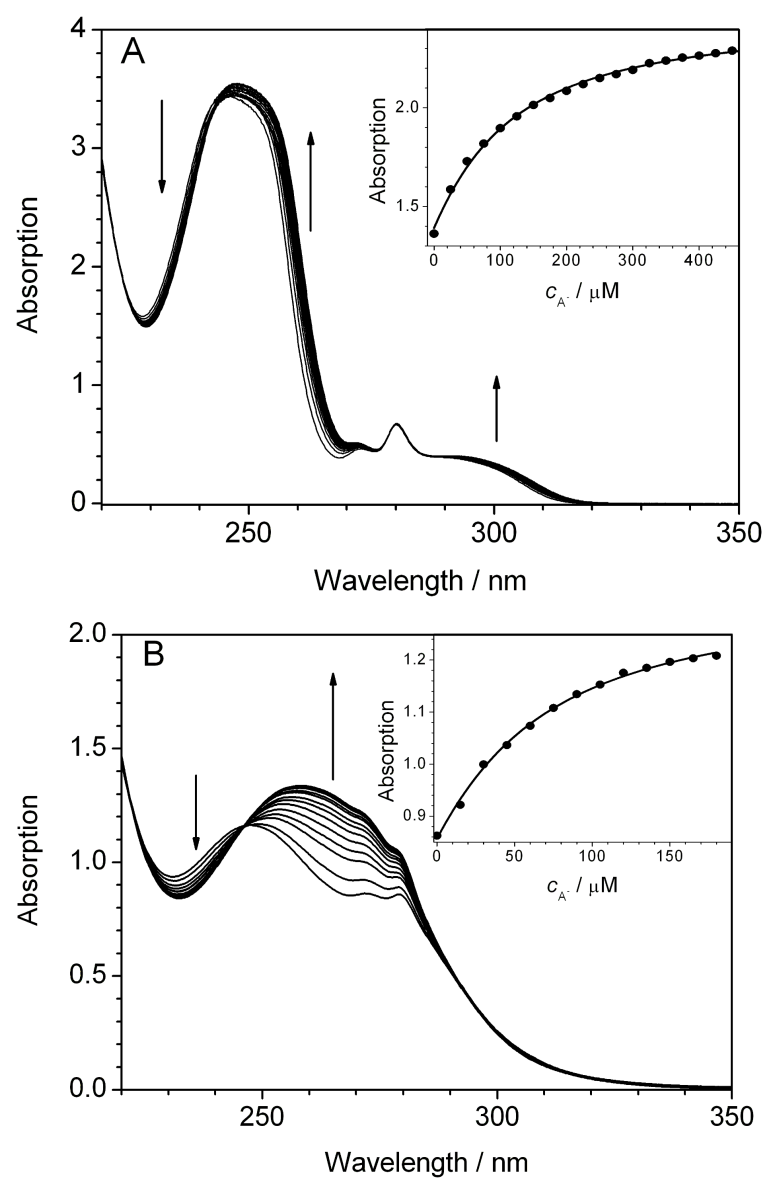

Figure 1: Photometric titration of $A$ ) tetrabutylammonium chloride (TBAC) to $1 \mathrm{~h}\left(c_{1 \mathrm{~h}}=50 \mu \mathrm{M}\right)$ and of $\left.\mathrm{B}\right)$ tetrabutylammonium (10S)camphorsulfonate $(\mathbf{S C S})$ to $1 \mathrm{i}\left(c_{1 \mathbf{i}}=30 \mu \mathrm{M}\right)$. Arrows indicate the changes of the absorption with increasing concentration of the salt Inset: Plot of the absorbance at $260 \mathrm{~nm}$ vs CTBAC (A) and at $272 \mathrm{~nm}$ vs Cscs (B); straight line represents the fit of the isotherm to a 1:1 stoichiometry. ence of complexation on the dibenzobarrelene chromophore. The binding isotherms from the spectrophotometric titration were fitted to a 1:1 stoichiometry and the resulting binding constants of the complexes were determined to be $K_{\mathrm{b}}=1.1 \times$ $10^{4} \mathrm{M}^{-1}$ for $\mathbf{1 h}$-TBAC and $K_{\mathrm{b}}=1.8 \times 10^{4} \mathrm{M}^{-1}$ for $\mathbf{1 i - S C S}$ (Figure 1). In addition, it was observed that the ${ }^{1} \mathrm{H}$ NMR spectroscopic signals of the $\mathrm{NH}$ protons of $\mathbf{1 h}$ (from 6.63 and 9.34 to 7.66 and 10.20) as well as the one of the methine proton (from 4.54 to 4.35) and of the $\mathrm{OH}$ proton (from 5.22 to 5.14) of the mandelate were significantly shifted upon the addition of (S)-mandelate (SMD) [in $\left.\left(\mathrm{CD}_{3}\right)_{2} \mathrm{SO}\right)$ ]. The corresponding Job plot confirms the 1:1 complex between $\mathbf{1 h}$ and SMD (Supporting Information File 1). Moreover, complex formation was confirmed by a weak NOE effect, as determined by ROESY NMR experiments, between the protons in the ortho position of the phenyl group of the mandelate and the bis(trifluoro)phenyl groups of $\mathbf{1 h}$.

Since it was demonstrated that the ureido- and thioureidosubstituted dibenzobarrelene derivatives $\mathbf{1 h}$ and $\mathbf{1 i}$ associate with anions, experiments were carried out to assess whether a stereoselective DPM rearrangement of $\mathbf{1 h}$ may be induced by a bound chiral anion. The initial experiments were performed with $(S)$-mandelate (SMD). Thus, a complex of the dibenzobarrelene $\mathbf{1 h}$ with SMD was irradiated in acetone solution at different concentrations and with varied host-guest ratios (Table 1, entries 1-5). The enantiomeric ratio (er) of the dibenzosemibullvalene product was determined by ${ }^{1} \mathrm{H}$ NMR spectroscopy with SMD as chiral shift reagent, as it turned out that this additive induces a significant separation of the protons of the enantiomers of $\mathbf{2 h}$ (Supporting Information File 1). The absolute configuration of the products was not determined. The photoreaction proceeded rapidly with full conversion in 4-6 hours with moderate stereoselectivity (68:32 er) in the presence of 1.1 molar equiv of the chiral mandelate. Variations of the host-guest ratio $\left(c_{1 \mathbf{h}}: c_{\text {anion }}=1: 0.5,1: 2.1,1: 5\right)$ led to a decrease of the stereoselectivity. In addition, changes in the concentration of the dibenzobarrelene $\mathbf{1 h}$ did not have a significant influence on the stereoselectivity of the reaction. Based on these results, the following experiments were carried out with a concentration of $0.25 \mathrm{mM}$ for the dibenzobarrelene derivative $\mathbf{1 h}$ and 1.1 molar equiv of the chiral additive (Table 1 , entries 6-10). Notably, the $(R)$-enantiomer of mandelate induced the same extent of stereoselectivity with the reverse ratio of products. For comparison, the photoreaction of dibenzobarrelene 1h was performed in the presence of other chiral anions, namely $(R)$-thiazolidine-4-carboxylate (RTZ), $(S)$-camphor-10sulfonate (SCS), $(R)$-carnitine (RCN), and (2S)-1[(benzyloxy)carbonyl]-2-pyrrolidinecarboxylate (SCP) (Figure 2). In each case, the induced stereoselectivity was significantly lower than that induced by $(S)$-mandelate. 


\begin{tabular}{|c|c|c|c|c|c|}
\hline Entry & Solvent $^{a}$ & Anion $^{b}$ & $c_{1 \mathrm{~h}} / \mathrm{mM}$ & $c_{1 \mathrm{~h}}: c_{\text {anion }}$ & $e^{c}$ \\
\hline 1 & Acetone & SMD & 0.25 & $1: 0.5$ & $45: 55$ \\
\hline 2 & Acetone & SMD & 0.25 & $1: 1.1$ & $32: 68$ \\
\hline 3 & Acetone & SMD & 0.50 & $1: 1.1$ & $33: 67$ \\
\hline 4 & Acetone & SMD & 0.50 & $1: 2.1$ & $41: 59$ \\
\hline 5 & Acetone & SMD & 0.50 & $1: 5.0$ & $47: 53$ \\
\hline 6 & Acetone & RMD & 0.25 & $1: 1.1$ & $67: 33$ \\
\hline 7 & Acetone & RTZ & 0.25 & $1: 1.1$ & $59: 41$ \\
\hline 8 & Acetone & SCS & 0.25 & $1: 1.1$ & $44: 56$ \\
\hline 9 & Acetone & SCP & 0.25 & $1: 1.1$ & $53: 47$ \\
\hline 10 & MeCN-MeOH 1:1 & $\mathrm{RCN}$ & 0.25 & $1: 1.1$ & $47: 53$ \\
\hline 11 & Acetonitrile & SMD & 0.25 & $1: 1.1$ & $40: 60$ \\
\hline 12 & Methanol & SMD & 0.25 & $1: 1.1$ & $48: 52$ \\
\hline 13 & Ethanol & SMD & 0.25 & $1: 1.1$ & $49: 51$ \\
\hline 14 & 2-Propanol & SMD & 0.25 & $1: 1.1$ & $50: 50$ \\
\hline 15 & Acetone-THF 1:9 & SMD & 0.25 & $1: 1.1$ & $45: 55$ \\
\hline 16 & Acetone-EtOAc 1:9 & SMD & 0.25 & $1: 1.1$ & $35: 65$ \\
\hline 17 & Acetone-Benzene 1:9 & SMD & 0.25 & $1: 1.1$ & $44: 56$ \\
\hline
\end{tabular}

${ }^{a}$ Conditions described in the Experimental Section; amount of $\mathbf{2 h}$ in reaction mixture: $>90 \%$ in all cases. ${ }^{b}$ Except for SCN used as tetrabutylammonium salts. ${ }^{\mathrm{C}} \mathrm{er}=$ enantiomeric ratio, determined by ${ }^{1} \mathrm{H}$ NMR spectroscopic analysis with 5 molar equiv of SMD as the shift reagent; estimated error: $\pm 3 \%$ of the given data. Each measurement was carried out twice to ensure the reproducibility.<smiles>O=C([O-])C(O)c1ccccc1</smiles>

SMD<smiles>O=C([O-])C(O)c1ccccc1</smiles>

RMD<smiles>O=C([O-])[C@@H]1CSCN1</smiles>

RTZ<smiles>CC1(C)C2CCC1(CS(=O)(=O)O)C(=O)C2</smiles>

SCS<smiles>C[N+](C)(C)C[C@@H](O)CC(=O)[O-]</smiles>

RCN<smiles>O=C([O-])[C@@H]1CCCN1C(=O)OCc1ccccc1</smiles>

SCP

Figure 2: Structures of chiral additives employed in DPM rearrangements.

The influence of the solvent on the DPM rearrangement of compound $\mathbf{1 h}$ was also investigated in the presence of $(S)$ mandelate (Table 1, entries 11-17). The low solubility of $\mathbf{1 h}$ in non-polar solvents required the addition of $10 \%$ acetone as co-solvent to give a homogeneous solution. Notably, a small but significant stereoselectivity of the DPM rearrangement of 1h was only observed in acetone or ethyl acetate/acetone (32:68 and 35:65 er), whereas in acetonitrile (40:60 er), THF (45:55 er) or $\mathrm{MeOH}, \mathrm{EtOH}$ or 2-PrOH (50:50 er) the DPM rearrangement of compound $\mathbf{1 h}$ proceeds with very low or no selectivity.

In additional experiments, the photoreactions of the thioureidosubstituted dibenzobarrelene derivative $\mathbf{1 i}$ were studied with chiral mandelate, camphorsulfonate and binaphthyl phosphonate in a variety of solvents including acetone, acetonitrile, ethyl acetate, dichloromethane, and benzene. Although the
DPM rearrangement of the dibenzobarrelene 1i took place readily upon irradiation and the semibullvalene photoproducts were isolated by column chromatography in very good yields, none of these products proved to be enantiomerically enriched, as determined by ${ }^{1} \mathrm{H}$ NMR experiments with SMD as the chiral shift reagent.

\section{Discussion}

It is well established that the regio- and stereoselectivity of a photoreaction may be induced by the selective preorganization of the substrates by hydrogen bonding between neutral organic functionalities with an appropriate substitution pattern or by complexation of crown-ether units to cationic guest molecules [1-3]. In contrast, the selective anion recognition has not been employed systematically to influence the photochemical properties of a substrate, although such supramolecular recep- 
tor-anion interactions have been used in the organocatalysis of ground-state reactions [40-44]. It should be noted that the supramolecular interactions between anions and ureido- or thioureido-substituted fluorophores have been used elegantly for the fluorimetric detection of the anion [46], and the photophysical background has been evaluated in detail [47], but the influence of the binding event on the photochemical properties has not been assessed. In this regard, the studies of the photoreactivity of the dibenzobarrelene derivatives $\mathbf{1 h}$ and $\mathbf{1 i}$ provide useful initial information about the potential of anion-controlled photoreactions.

The fact that the DPM rearrangement of ureido-substituted dibenzobarrelene derivative $\mathbf{1 h}$ takes place even without external sensitizers suggests that an efficient intersystem crossing (ISC) process exists for the excited chromophore $\mathbf{1 h}$ that directs the photoreaction predominately to the triplet pathway. The 3,5bis(trifluoromethyl)phenyl substituent may be responsible for the ISC, because $m$-bis(trifluoromethyl)benzene has an ISC quantum yield of $\Phi_{\text {ISC }}=0.12\left(\lambda_{\mathrm{ex}}=254 \mathrm{~nm}\right)$ in the gas phase, and the latter compound is able to sensitize a triplet-state $E / Z$ isomerization of alkenes [48]. On the other hand, the thioureido-substituted dibenzobarrelene derivative 1i does not undergo a DPM rearrangement upon direct irradiation, despite the potentially sensitizing 3,5-bis(trifluoromethyl)phenyl substituents. Notably, not even the commonly employed sensitizer acetone is capable of inducing the DPM rearrangement of 1i. Considering the different photophysical and photochemical properties of the carbonyl and thiocarbonyl chromophores [49], it may be that a similar difference exists between urea and thiourea functionalities. Thiocarbonyl groups usually have high ISC rates, but they are also prone to self-quenching [49] and act as efficient quenchers for triplet reactions [50]. Thus, in analogy to the properties of the thiocarbonyl chromophore, it is proposed that the thioureido functionality in $\mathbf{1 i}$ quenches the triplet excited-state, most likely by the intramolecular selfquenching of the two proximate thiourea groups. Interestingly, upon association of the thiourea units with anions, the DPM reactivity of compound $\mathbf{1} \mathbf{i}$ is regained. This observation is consistent with the shorter reaction time of the DPM rearrangement of the ureido-substituted derivative $\mathbf{1 h}$ upon association with anions. Since the photometric titrations clearly indicate complex formation, it may be assumed that the decreased reaction times are due to restricted molecular flexibility of the ureidoand thioureido substituents within the complex. Specifically, the deactivation of the excited-state by conformational relaxation is suppressed upon complex formation leading to increased quantum yields of the photoreaction. Nevertheless, in the case of the thioureido-substituted derivative $1 \mathbf{i}$ additional effects need to be considered to explain the drastic change of the photochemical properties. Apparently, the quenching effect of the thioureido substituents on the triplet reaction is no longer effective after the association with anions. Presumably, the complexed anions affect the properties of the $\mathrm{C}=\mathrm{S}$ bond in $\mathbf{1 i}$, leading to changes in excited-state reactivity, as has been shown for hydrogen bonded thiocarbonyl compounds in a theoretical study [51]. For comparison, it should be noted that the ISC rate constant of the thioureido-substituted anthracene 4 (Figure 3), $k_{\mathrm{ISC}}=1.1 \times 10^{9} \mathrm{~s}^{-1}\left(\mathrm{CH}_{3} \mathrm{CN}\right)$, even decreases by one order of magnitude upon association with acetate [27]. In that case, however, the absorption of the anthracene and the (trifluoromethyl)phenylthiourea part are well separated and the anthracene is excited selectively at lower energy. Moreover, as there is only one thioureido substituent attached to the anthracene in 4, self-quenching can only take place in a bimolecular process, which is negligible at the low concentration employed in these experiments.

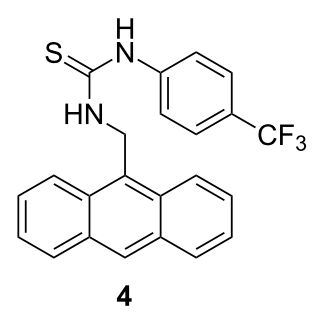

Figure 3: Structure of anthracene-thiourea conjugate 4

It was demonstrated that the complexation of chiral carboxylates by the ureido substituents of the dibenzobarrelene derivative $\mathbf{1 h}$ may be employed, in principle, to induce a stereoselective DPM rearrangement. The lack of stereoselectivity in competitive protic solvents, namely alcohols, indicates the relevance of the hydrogen bonding between the anion and the urea group for chiral induction. As the best selectivities were observed in the presence of 1 molar equiv of the mandelate ion, it may be deduced that the stereoselectivity of the reaction mainly originates from a 1:1 complex between $\mathbf{1 h}$ and the mandelate SMD (1h-SMD) (Figure 4), thus resembling known complexes, in which a bisurea receptor uses all four $\mathrm{NH}$ hydrogen for chelating hydrogen bonding to carboxylate in a 1:1 complex [52-54]. The fact that mandelate induces a significantly higher selectivity than the other employed anions may be explained by additional interactions of the hydroxy or phenyl substituent of the mandelate with the bis(trifluoromethyl)phenyl substituent or with the ureido substituent. Presumably, in complex 1h-SMD one initial vinyl-benzo bridging (pathway a or b) is preferred due to steric or conformational restraints; however, this effect is only small, but significant, as indicated by the moderate stereoselectivity (68:32 er). 


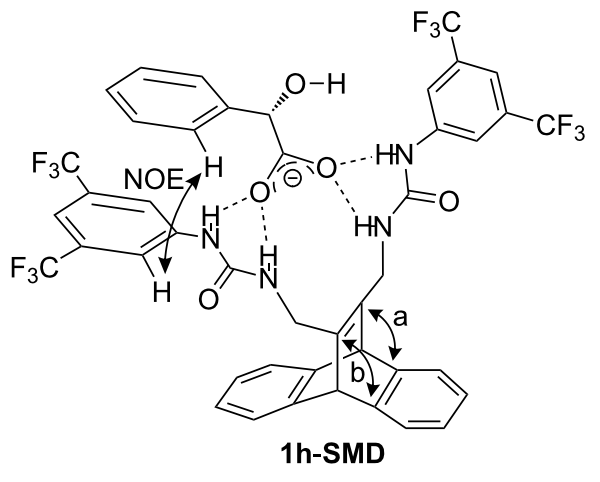

Figure 4: Proposed structure of the complex between $1 \mathrm{~h}$ and mandelate SMD.

At present, the reason for the lack of stereoselectivity of the DPM rearrangement of the thioureido-substituted dibenzobarrelene 1i upon complexation of chiral anions is not clear. Nevertheless, it has been shown that neighboring aryl substituents decrease the anion-binding ability of thiourea derivatives because of the steric repulsion between the ortho-substituents and the sulfur atom [55]. This effect may also suppress the formation of a stable 1:1 complex between the chelating thioureido functionalities in $\mathbf{1 i}$ and anions, such that an inducing effect of the anion on the photoreaction of the dibenzobarrelene is not operative.

\section{Conclusion}

In summary, it was demonstrated that the photochemical properties of the bisureido- and bisthioureido-substituted dibenzobarralene derivatives $\mathbf{1 h}$ and $\mathbf{1 i}$ may be influenced by complex formation with appropriate anions. In general, the photoreactivity of the substrates is significantly increased upon association with anions. Specifically, the DPM rearrangement of the thioureido derivative $\mathbf{1 i}$ to give the dibenzosemibullvalene $\mathbf{2 i}$ can only be performed successfully when the self-quenching of the triplet state is suppressed by complex formation. At the same time it was shown in preliminary experiments that the association of chiral carboxylates with $\mathbf{1 h}$ induces a stereoselective DPM rearrangement. So far, the selectivities are very low; however, these observations demonstrate that anion-controlled stereoselective DPM rearrangements may be accomplished in principle. Therefore, it is proposed that this methodology may be optimized in future studies, thus providing a complementary tool to perform stereoselective photoreactions based on supramolecular interactions.

\section{Experimental}

General remarks: The NMR spectra were recorded on a Bruker Avance $400\left({ }^{1} \mathrm{H}\right.$ NMR: $400 \mathrm{MHz} ;{ }^{13} \mathrm{C}$ NMR: $\left.100 \mathrm{MHz}\right)$ and a Varian NMR system $600\left({ }^{1} \mathrm{H}\right.$ NMR: $600 \mathrm{MHz} ;{ }^{13} \mathrm{C}$ NMR: $150 \mathrm{MHz}) .{ }^{1} \mathrm{H}$ NMR chemical shifts are relative to tetramethylsilane $\left(\delta_{\mathrm{TMS}}=0.00 \mathrm{ppm}\right)$, and ${ }^{13} \mathrm{C} \mathrm{NMR}$ chemical shifts refer to either the signal of tetramethylsilane $\left(\delta_{\mathrm{TMS}}=0.00 \mathrm{ppm}\right)$ or the solvent signals $\left[\left(\mathrm{CD}_{3}\right)_{2} \mathrm{CO}: 29.8 \mathrm{ppm},\left(\mathrm{CD}_{3}\right)_{2} \mathrm{SO}\right.$ : $39.5 \mathrm{ppm}$ ]. Absorption spectra were recorded on a Varian 100 Bio spectrometer at $25^{\circ} \mathrm{C}$. Melting points were determined on a Büchi $510 \mathrm{~K}$ and are uncorrected. Mass spectra were recorded on a Hewlett-Packard HP 5968 (EI) and a Finnigan LCQ Deca instrument (ESI). Elemental analyses were performed on a KEKA-tech EuroEA combustion analyzer by Mr. H. Bodenstedt, Organic Chemistry I, University of Siegen. TLC analyses were performed on silica-gel sheets (Macherey-Nagel Polygram Sil G/UV 254$)$. Unless otherwise mentioned, commercially available chemicals were reagent grade and were used without further purification. Tetrabutylammonium hydroxide in $\mathrm{MeOH}$ $(1.0 \mathrm{M})$ and $(S)$-camphor-10-sulfonic acid were obtained from Aldrich. $(R)$-Mandelic acid and $(S)$-mandelic acid were obtained from Fluka. $(R)$-Thiazolidine-4-carboxylic acid and (2S)-1[(benzyloxy)carbonyl]-2-pyrrolidinecarboxylic acid were obtained from Acros. (R)-Carnitine was obtained from Alfa-Aesar. Preparative column chromatography was performed on MN Silica Gel $60 \mathrm{M}$ (particle size 0.04-0.063 mm, 230-440 mesh).

Irradiations were performed with a TQ150 middle-pressure mercury lamp (Heraeus, UV-Consulting Peschl), which was placed inside a quartz cooling tube. The reaction mixture was placed ca. $10-15 \mathrm{~cm}$ in front of the lamp.

General procedure for the preparation of bisurea- and bisthiourea derivatives of dibenzobarrelene (GP1): The isocyanate or isothiocyanate derivative (1.1 molar equiv) was added to a stirred solution of 11,12-bis(aminomethyl)-9,10dihydro-9,10-ethenoanthracene (1d, 0.45-10.0 mmol) [45] in $\mathrm{CH}_{2} \mathrm{Cl}_{2}(3 \mathrm{~mL} / \mathrm{mmol})$ at $0{ }^{\circ} \mathrm{C}$. A white or pale yellow solid precipitated shortly after the addition of iso(thio)cyanate. The mixture was stirred for $2 \mathrm{~h}$ at room temperature, and the solid collected by filtration or recrystallization directly from the reaction mixture depending on the solubility of the product.

11,12-Bis( $N^{\prime}-n$-butylureidomethyl)-9,10-dihydro-9,10-ethenoanthracene (1e): Prepared from dibenzobarrelene 1d (554 mg, $2.00 \mathrm{mmol}$ ) according to GP1, collected by filtration and dried in vacuo. Yield $732 \mathrm{mg}$ (1.77 mmol, 79\%), white powder, $\mathrm{mp}>320{ }^{\circ} \mathrm{C}$ (dec.). ${ }^{1} \mathrm{H}$ NMR $\left[400 \mathrm{MHz},\left(\mathrm{CD}_{3}\right)_{2} \mathrm{SO}\right]$ : $\delta 0.88\left(\mathrm{t}, J=7 \mathrm{~Hz}, 6 \mathrm{H}, \mathrm{CH}_{3}\right), 1.23-1.34\left(\mathrm{~m}, 8 \mathrm{H}, \mathrm{CH}_{2}\right)$, 2.95-2.99 (m, 4H, CH $2 \mathrm{NH}), 3.83\left(\mathrm{~d}, J=7 \mathrm{~Hz}, 4 \mathrm{H}, \mathrm{CH}_{2} \mathrm{C}=\mathrm{C}\right)$, $5.08(\mathrm{~s}, 2 \mathrm{H}, \mathrm{CH}), 5.83-5.85$ ( $\mathrm{m}, 4 \mathrm{H}, \mathrm{NH}), 6.91,7.22$ (AA'BB'system, $\left.8 \mathrm{H}, \mathrm{CH}_{\mathrm{ar}}\right) .{ }^{13} \mathrm{C} \mathrm{NMR}\left[100 \mathrm{MHz},\left(\mathrm{CD}_{3}\right)_{2} \mathrm{SO}\right]: \delta 14.1$ 
$\left(\mathrm{CH}_{3}\right), 19.9\left(\mathrm{CH}_{2}\right), 32.6\left(\mathrm{CH}_{2}\right), 38.0\left(\mathrm{CH}_{2}\right), 53.1(\mathrm{CH}), 122.9$ $\left(\mathrm{CH}_{\mathrm{ar}}\right), 124.5\left(\mathrm{CH}_{\mathrm{ar}}\right), 143.3\left(\mathrm{C}_{\mathrm{q}}\right), 146.6\left(\mathrm{C}_{\mathrm{q}}\right), 158.6(\mathrm{C}=\mathrm{O})$. Anal. Calcd for $\mathrm{C}_{34} \mathrm{H}_{28} \mathrm{~N}_{4} \mathrm{O}_{2}$ (460.6): C, 73.01; H, 7.88; N, 12.16. Found: C, 73.25; H, 7.95; N, 12.04 .

11,12-Bis( $N$ '-phenylureidomethyl)-9,10-dihydro-9,10-ethenoanthracene (1f): Prepared from dibenzobarrelene 1d (131 $\mathrm{mg}, 0.50 \mathrm{mmol}$ ) according to GP1 and collected by filtration and obtained as a white powder $(179 \mathrm{mg}, 0.36 \mathrm{mmol}$, 72\%), mp 309-312 ${ }^{\circ} \mathrm{C}$ (dec.). ${ }^{1} \mathrm{H}$ NMR [400 MHz, $\left.\left(\mathrm{CD}_{3}\right)_{2} \mathrm{SO}\right]$ : $\delta 4.07\left(\mathrm{~d}, J=5 \mathrm{~Hz}, 4 \mathrm{H}, \mathrm{CH}_{2}\right), 5.15(\mathrm{~s}, 2 \mathrm{H}, \mathrm{CH}), 6.37(\mathrm{t}, J=$ $5 \mathrm{~Hz}, 2 \mathrm{H}, \mathrm{NH}), 6.90-6.93\left(\mathrm{~m}, 6 \mathrm{H}, \mathrm{CH}_{\mathrm{ar}}\right), 7.20-7.41(\mathrm{~m}, 12 \mathrm{H}$, $\left.\mathrm{CH}_{\mathrm{ar}}\right), 8.29$ (s, 2H, NH). ${ }^{13} \mathrm{C}$ NMR [100 MHz, $\left.\left(\mathrm{CD}_{3}\right)_{2} \mathrm{SO}\right]$ :

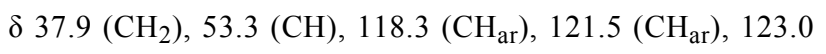
$\left(\mathrm{CH}_{\mathrm{ar}}\right), 124.6\left(\mathrm{CH}_{\mathrm{ar}}\right), 129.0\left(\mathrm{CH}_{\mathrm{ar}}\right), 140.8\left(\mathrm{C}_{\mathrm{q}}\right), 143.5\left(\mathrm{C}_{\mathrm{q}}\right)$, $146.5\left(\mathrm{C}_{\mathrm{q}}\right), 155.8(\mathrm{C}=\mathrm{O})$. MS (EI): $m / z=500\left[\mathrm{M}^{+}\right]$. Anal. Calcd for $\mathrm{C}_{34} \mathrm{H}_{28} \mathrm{~N}_{4} \mathrm{O}_{2}$ (500.6): C, 76.78; H, 5.64; N, 11.19. Found: $\mathrm{C}$, $76.68 ; \mathrm{H}, 5.67 ; \mathrm{N}, 11.12$.

11,12-Bis[ $N$ '-(4-n-butylphenyl)ureidomethyl]-9,10-dihydro9,10-ethenoanthracene (1g): Prepared from dibenzobarrelene 1d $(0.12 \mathrm{~g}, 0.45 \mathrm{mmol})$ according to GP1, collected by filtration and dried in vacuo. White amorphous solid, yield $0.21 \mathrm{~g}$ (0.34 mmol, 76\%), mp > $320{ }^{\circ} \mathrm{C} .{ }^{1} \mathrm{H}$ NMR [400 MHz, $\left.\left(\mathrm{CD}_{3}\right)_{2} \mathrm{SO}\right]: \delta 0.89$ (t, $\left.J=7 \mathrm{~Hz}, 6 \mathrm{H}, \mathrm{CH}_{3}\right), 1.26-1.55(\mathrm{~m}, 8 \mathrm{H}$, $\mathrm{CH}_{2} \mathrm{CH}_{2} \mathrm{CH}_{3}$ ), 2.47-2.50 (m, 4H, $\mathrm{PhCH}_{2} \mathrm{CH}_{2}$, partly overlapped with the solvent signal), $3.97(\mathrm{~d}, J=6 \mathrm{~Hz}, 4 \mathrm{H}$, $\left.\mathrm{C}=\mathrm{CCH}_{2}\right), 5.14(\mathrm{~s}, 2 \mathrm{H}, \mathrm{CH}), 6.06(\mathrm{t}, J=6 \mathrm{~Hz}, 2 \mathrm{H}, \mathrm{NH})$, 6.90-6.92 (m, 4H, $\left.\mathrm{CH}_{\mathrm{ar}}\right), 7.03-7.05\left(\mathrm{~m}, 4 \mathrm{H}, \mathrm{CH}_{\mathrm{ar}}\right), 7.25-7.29$ $\left(\mathrm{m}, 8 \mathrm{H}, \mathrm{CH}_{\mathrm{ar}}\right), 8.42(\mathrm{~s}, 2 \mathrm{H}, \mathrm{NH}) .{ }^{13} \mathrm{C} \mathrm{NMR} \mathrm{[100} \mathrm{MHz,}$ $\left.\left(\mathrm{CD}_{3}\right)_{2} \mathrm{SO}\right]: \delta 14.2\left(\mathrm{CH}_{3}\right), 22.1\left(\mathrm{CH}_{2}\right), 33.7\left(\mathrm{CH}_{2}\right), 34.5\left(\mathrm{CH}_{2}\right)$, $37.9\left(\mathrm{CH}_{2}\right), 53.3(\mathrm{CH}), 118.4\left(\mathrm{CH}_{\mathrm{ar}}\right), 123.0\left(\mathrm{CH}_{\mathrm{ar}}\right), 124.6$ $\left(\mathrm{CH}_{\mathrm{ar}}\right), 128.8\left(\mathrm{CH}_{\mathrm{ar}}\right), 135.3\left(\mathrm{CH}_{\mathrm{ar}}\right), 138.4\left(\mathrm{C}_{\mathrm{q}}\right), 143.5\left(\mathrm{C}_{\mathrm{q}}\right)$, $146.5\left(\mathrm{C}_{\mathrm{q}}\right), 155.9(\mathrm{C}=\mathrm{O})$. MS (EI): $m / z(\%)=613\left[\mathrm{M}^{+}\right]$. Anal. Calcd for $\mathrm{C}_{40} \mathrm{H}_{44} \mathrm{~N}_{4} \mathrm{O}_{2}$ (612.8): C, 78.40; H, 7.24; N, 9.14. Found: C, 78.12; H, 7.25; N, 9.09.

11,12-Bis $\left\{N^{\prime}\right.$-[3,5-bis(trifluoromethyl)phenyl]ureidomethyl\}-9,10-dihydro-9,10-ethenoanthracene (1h): Prepared from dibenzobarrelene $\mathbf{1 d}(0.13 \mathrm{~g}, 0.50 \mathrm{mmol})$ according to GP1. After filtration of the precipitate, the product was purified by recrystallization from $\mathrm{CH}_{2} \mathrm{Cl}_{2}$ /hexane and obtained as a white solid (0.33 g, $0.41 \mathrm{mmol}, 82 \%), \mathrm{mp}>300{ }^{\circ} \mathrm{C} .{ }^{1} \mathrm{H}$ NMR [400 MHz, $\left(\mathrm{CD}_{3}\right)_{2} \mathrm{CO}$ ]: $\delta 4.18\left(\mathrm{~d}, J=4 \mathrm{~Hz}, 4 \mathrm{H}, \mathrm{CH}_{2}\right), 5.25$ (s, $2 \mathrm{H}, \mathrm{CH}), 6.43$ (br s, 2H, NH), $6.86\left(\mathrm{~m}, 4 \mathrm{H}, \mathrm{CH}_{\mathrm{ar}}\right), 7.27$ (m, 4H, $\mathrm{CH}_{\mathrm{ar}}$ ), 7.51 (s, 2H, $\mathrm{CH}_{\mathrm{ar}}$ ), 8.03 (br s, $4 \mathrm{H}, \mathrm{CH}_{\mathrm{ar}}$ ), 8.64 (br s, $2 \mathrm{H}$, $\mathrm{NH}) .{ }^{13} \mathrm{C}$ NMR $\left[100 \mathrm{MHz},\left(\mathrm{CD}_{3}\right)_{2} \mathrm{CO}\right]: \delta 38.3\left(\mathrm{CH}_{2}\right), 53.3$ $(\mathrm{CH}), 113.9\left(\mathrm{CH}_{\mathrm{ar}}\right), 117.7\left(\mathrm{CH}_{\mathrm{ar}}\right), 122.4\left(\mathrm{CH}_{\mathrm{ar}}\right), 123.0\left(\mathrm{CH}_{\mathrm{ar}}\right)$, 124.6 $\left(\mathrm{CH}_{\mathrm{ar}}\right), 125.1\left(\mathrm{CH}_{\mathrm{ar}}\right), 130.7\left(\mathrm{CH}_{\mathrm{ar}}\right), 131.1\left(\mathrm{CH}_{\mathrm{ar}}\right), 142.7$ $\left(\mathrm{C}_{\mathrm{q}}\right), 143.4\left(\mathrm{C}_{\mathrm{q}}\right), 146.4\left(\mathrm{C}_{\mathrm{q}}\right), 155.4(\mathrm{C}=\mathrm{O}) . \mathrm{UV}(\mathrm{MeCN}): \lambda_{\max }$ $(\log \varepsilon)=229$ (4.49), 246 (4.86), 272 (4.01), 280 (4.13). MS
$\left(\mathrm{ESI}^{-}\right): m / z(\%)=771(100)[\mathrm{M}-\mathrm{H}]^{-}$. Anal. Calcd for $\mathrm{C}_{36} \mathrm{H}_{24} \mathrm{~F}_{12} \mathrm{~N}_{4} \mathrm{O}_{2}$ (772.6): C, 55.97; H, 3.13; N, 7.25. Found: $\mathrm{C}$, $55.58 ; \mathrm{H}, 2.85 ; \mathrm{N}, 7.04$.

11,12-Bis $\left\{N^{\prime}-[3,5-(b i s t r i f l u o r o m e t h y l) p h e n y l]\right.$ thioureidomethyl $\}-9,10-$ dihydro-9,10-ethenoanthracene (1i): Prepared from dibenzobarrelene 1 d $(0.13 \mathrm{~g}, 0.50 \mathrm{mmol})$ according to GP1 and obtained by recrystallization from $\mathrm{CH}_{2} \mathrm{Cl}_{2}$ /hexane as a white solid $(0.34 \mathrm{~g}, 0.43 \mathrm{mmol}, 86 \%)$, $\mathrm{mp}>300{ }^{\circ} \mathrm{C} .{ }^{1} \mathrm{H}$ NMR [600 MHz, $\left.\left(\mathrm{CD}_{3}\right)_{2} \mathrm{CO}\right]: \delta 4.66(\mathrm{~d}$, $\left.J=4 \mathrm{~Hz}, 4 \mathrm{H}, \mathrm{CH}_{2}\right), 5.36(\mathrm{~s}, 2 \mathrm{H}, \mathrm{CH}), 6.92\left(\mathrm{~m}, 4 \mathrm{H}, \mathrm{CH}_{\mathrm{ar}}\right)$, 7.30-7.32 (m, 4H, $\left.\mathrm{CH}_{\mathrm{ar}}\right), 7.73\left(\mathrm{~m}, 4 \mathrm{H}, \mathrm{CH}_{\mathrm{ar}}\right.$ overlapped with $\mathrm{NH}), 8.25-8.26\left(\mathrm{~m}, 4 \mathrm{H}, \mathrm{CH}_{\mathrm{ar}}\right), 9.57$ (br s, 2H, NH). ${ }^{13} \mathrm{C}$ NMR [150 MHz, $\left.\left(\mathrm{CD}_{3}\right)_{2} \mathrm{CO}\right]: \delta=43.4\left(\mathrm{CH}_{2}\right), 54.2(\mathrm{CH})$, $117.9\left(\mathrm{CH}_{\mathrm{ar}}\right), 121.5\left(\mathrm{CH}_{\mathrm{ar}}\right), 123.6\left(\mathrm{CH}_{\mathrm{ar}}\right), 125.3\left(\mathrm{CH}_{\mathrm{ar}}\right)$, $127.0\left(\mathrm{CH}_{\mathrm{ar}}\right), 132.0\left(\mathrm{CH}_{\mathrm{ar}}\right), 142.4\left(\mathrm{C}_{\mathrm{q}}\right), 144.1\left(\mathrm{C}_{\mathrm{q}}\right), 146.8\left(\mathrm{C}_{\mathrm{q}}\right)$, $182.4(\mathrm{C}=\mathrm{O})$. UV $(\mathrm{MeCN}): \lambda_{\max }(\log \varepsilon)=230(4.49), 246$ (4.59), 272 (4.46), 280 (4.47). MS (ESI): $m / z(\%)=803$ (100) $[\mathrm{M}-\mathrm{H}]^{-}$. Anal. Calcd for $\mathrm{C}_{36} \mathrm{H}_{24} \mathrm{~F}_{12} \mathrm{~N}_{4} \mathrm{~S}_{2}$ (804.7): C, 53.73; $\mathrm{H}$, 3.01; N, 6.96; S, 7.97. Found: C, 53.58; H, 2.79; N, 6.84; S, 7.97 .

General procedure for the synthetic photolysis in solution (GP2): Solutions of the substrate $\left(10^{-3}-10^{-2} \mathrm{~mol} / \mathrm{l}\right)$ were placed in a Duran flask (acetone) or quartz test tube (other solvents), and argon gas was bubbled carefully through the solution for at least $20 \mathrm{~min}$. The solution was irradiated for 4-15 h with stirring until the starting material was fully converted as determined by TLC or ${ }^{1} \mathrm{H}$ NMR spectroscopic analysis. After evaporation of the solvent in vacuo, the photolysate was analyzed by ${ }^{1} \mathrm{H}$ NMR spectroscopy. In preparative experiments, the photoproduct was isolated by recrystallization or column chromatography.

4b,8b-Dihydro-8c,8e-bis $\left\{N^{\prime}\right.$-[3,5-bis(trifluoromethyl)phenyl] ureidomethyl $\}$ dibenzo $[a, f]$ cyclopropa $[c, d]$ pentalene (2h): Prepared by irradiation of $\mathbf{1 h}(48.0 \mathrm{mg}, 0.06 \mathrm{mmol})$ in acetone solution according to GP2 and obtained as white crystals (29.0 mg, $0.04 \mathrm{mmol}, 60 \%)$, mp 246-247 ${ }^{\circ} \mathrm{C} .{ }^{1} \mathrm{H}$ NMR [600 MHz, $\left(\mathrm{CD}_{3}\right)_{2} \mathrm{CO}$ ]: $\delta 3.22(\mathrm{~s}, 1 \mathrm{H}, \mathrm{CH}), 3.78(\mathrm{dd}, J=15,6$ $\left.\mathrm{Hz}, 1 \mathrm{H}, \mathrm{CH}_{2}\right), 3.82\left(\mathrm{dd}, J=15,6 \mathrm{~Hz}, 1 \mathrm{H}, \mathrm{CH}_{2}\right), 3.94(\mathrm{dd}, J=$ $\left.15,6 \mathrm{~Hz}, 1 \mathrm{H}, \mathrm{CH}_{2}\right), 4.44\left(\mathrm{dd}, J=15,6 \mathrm{~Hz}, 1 \mathrm{H}, \mathrm{CH}_{2}\right), 4.63$ (s, $1 \mathrm{H}, \mathrm{CH}), 6.42(\mathrm{t}, J=5 \mathrm{~Hz}, 1 \mathrm{H}, \mathrm{NH}), 6.53(\mathrm{t}, J=5 \mathrm{~Hz}, 1 \mathrm{H}, \mathrm{NH})$, 6.99-7.05 (m, 4H, $\left.\mathrm{CH}_{\mathrm{ar}}\right), 7.21-7.25\left(\mathrm{~m}, 3 \mathrm{H}, \mathrm{CH}_{\mathrm{ar}}\right), 7.36-7.38$ $\left(\mathrm{m}, 1 \mathrm{H}, \mathrm{CH}_{\mathrm{ar}}\right), 7.49\left(\mathrm{~s}, 2 \mathrm{H}, \mathrm{CH}_{\mathrm{ar}}\right), 8.09\left(\mathrm{~s}, 2 \mathrm{H}, \mathrm{CH}_{\mathrm{ar}}\right), 8.13$ (s, $\left.2 \mathrm{H}, \mathrm{CH}_{\mathrm{ar}}\right), 8.75(\mathrm{~s}, 1 \mathrm{H}, \mathrm{NH}), 8.81(\mathrm{~s}, 1 \mathrm{H}, \mathrm{NH}) .{ }^{13} \mathrm{C} \mathrm{NMR}[150$ $\left.\mathrm{MHz},\left(\mathrm{CD}_{3}\right)_{2} \mathrm{CO}\right]: \delta 41.3\left(\mathrm{CH}_{2}\right), 41.4\left(\mathrm{CH}_{2}\right), 46.7(\mathrm{CH}), 53.3$ $\left(\mathrm{C}_{\mathrm{q}}\right), 58.8\left(\mathrm{C}_{\mathrm{q}}\right), 67.4(\mathrm{CH}), 115.6\left(\mathrm{CH}_{\mathrm{ar}}\right), 115.6\left(\mathrm{CH}_{\mathrm{ar}}\right), 115.6$ $\left(\mathrm{CH}_{\mathrm{ar}}\right), 115.7\left(\mathrm{CH}_{\mathrm{ar}}\right), 119.3\left(\mathrm{CH}_{\mathrm{ar}}\right), 119.3\left(\mathrm{CH}_{\mathrm{ar}}\right), 123.4\left(\mathrm{CH}_{\mathrm{ar}}\right)$, $123.4\left(\mathrm{CH}_{\mathrm{ar}}\right), 124.5\left(\mathrm{CH}_{\mathrm{ar}}\right), 124.6\left(\mathrm{C}_{\mathrm{q}}\right), 125.8\left(\mathrm{CH}_{\mathrm{ar}}\right), 126.3$ $\left(\mathrm{C}_{\mathrm{q}}\right), 126.4\left(\mathrm{CH}_{\mathrm{ar}}\right), 126.6\left(\mathrm{CH}_{\mathrm{ar}}\right), 128.1\left(\mathrm{CH}_{\mathrm{ar}}\right), 128.2\left(\mathrm{CH}_{\mathrm{ar}}\right)$, 
$128.3\left(\mathrm{CH}_{\mathrm{ar}}\right), 128.5\left(\mathrm{CH}_{\mathrm{ar}}\right), 133.2\left(\mathrm{C}_{\mathrm{q}}\right), 133.2\left(\mathrm{C}_{\mathrm{q}}\right), 133.4\left(\mathrm{C}_{\mathrm{q}}\right)$, $133.4\left(\mathrm{C}_{\mathrm{q}}\right), 139.9\left(\mathrm{CH}_{\mathrm{ar}}\right), 140.1\left(\mathrm{CH}_{\mathrm{ar}}\right), 144.4\left(\mathrm{C}_{\mathrm{q}}\right), 144.6\left(\mathrm{C}_{\mathrm{q}}\right)$, $151.8\left(\mathrm{C}_{\mathrm{q}}\right), 152.8\left(\mathrm{C}_{\mathrm{q}}\right), 156.7(\mathrm{C}=\mathrm{O}), 157.2(\mathrm{C}=\mathrm{O})$. MS (ESI): $m / z(\%)=771(100)[\mathrm{M}-\mathrm{H}]^{-}$. An analytical sample was obtained by recrystallization from ethyl acetate/hexane and contained one equiv of ethyl acetate as the lattice solvent. Anal. Calcd for $\mathrm{C}_{36} \mathrm{H}_{24} \mathrm{~F}_{12} \mathrm{~N}_{4} \mathrm{O}_{2}$. EtOAc (860.7): C, 55.82; H, 3.75; N, 6.51. Found: C, 55.93; H, 3.51; N, 6.45 .

4b,8b-Dihydro-8c,8e-bis $\left\{N^{\prime}\right.$-[3,5-bis(trifluoromethyl)phenyl $]$ thioureidomethyl $\}$ dibenzo $[a, f]$ cyclopropa $[c, d]$ pentalene (2i): Prepared by photoreaction of $\mathbf{1 i}(0.20 \mathrm{~g}, 0.25 \mathrm{mmol})$ in acetonitrile solution in the presence of 2 molar equiv of ammonium chloride according to GP2. After the irradiation the inorganic components were removed by column filtration $\left(\mathrm{SiO}_{2}\right.$ EtOAc/hexane 1/2, v/v), and the residue was recrystallized from ethyl acetate/hexane to give light yellow crystals (104 mg, $0.13 \mathrm{mmol}, 52 \%$ ), mp $181-182{ }^{\circ} \mathrm{C} .{ }^{1} \mathrm{H}$ NMR [600 MHz, $\left(\mathrm{CD}_{3}\right)_{2} \mathrm{CO}$ ]: $\delta 1.20\left(\mathrm{t}, J=7 \mathrm{~Hz}, 3 \mathrm{H}, \mathrm{CH}_{3}\right), 3.43(\mathrm{~s}, 1 \mathrm{H}, \mathrm{CH})$, $4.05\left(\mathrm{q}, J=7 \mathrm{~Hz}, 2 \mathrm{H}, \mathrm{CH}_{2}\right), 4.22(\mathrm{~d}, J=13 \mathrm{~Hz}, 1 \mathrm{H}$, NHCHHC), 4.29 (d, $J=13 \mathrm{~Hz}, 1 \mathrm{H}, \mathrm{NHCHHC}), 4.48$ (d, $J=$ $13 \mathrm{~Hz}, 1 \mathrm{H}, \mathrm{NHCH} H \mathrm{C}), 4.74$ (d, $J=13 \mathrm{~Hz}, 1 \mathrm{H}, \mathrm{NHCH} H \mathrm{C})$, $4.76(\mathrm{~s}, 1 \mathrm{H}, \mathrm{CH}), 7.00-7.09\left(\mathrm{~m}, 5 \mathrm{H}, \mathrm{CH}_{\mathrm{ar}}\right), 7.24-7.28(\mathrm{~m}, 3 \mathrm{H}$, $\left.\mathrm{CH}_{\mathrm{ar}}\right), 7.36-7.38\left(\mathrm{~m}, 1 \mathrm{H}, \mathrm{CH}_{\mathrm{ar}}\right), 7.67\left(\mathrm{~s}, 2 \mathrm{H}, \mathrm{CH}_{\mathrm{ar}}\right), 7.81(\mathrm{~s}, 1 \mathrm{H}$, $\mathrm{NH}), 7.89(\mathrm{~s}, 1 \mathrm{H}, \mathrm{NH}), 8.23\left(\mathrm{~s}, 2 \mathrm{H}, \mathrm{CH}_{\mathrm{ar}}\right), 8.32\left(\mathrm{~s}, 2 \mathrm{H}, \mathrm{CH}_{\mathrm{ar}}\right)$, $9.45(\mathrm{~s}, 1 \mathrm{H}, \mathrm{NH}), 9.53(\mathrm{~s}, 1 \mathrm{H}, \mathrm{NH}) .{ }^{13} \mathrm{C} \mathrm{NMR}[150 \mathrm{MHz}$, $\left.\left(\mathrm{CD}_{3}\right)_{2} \mathrm{CO}\right)$ ]: $\delta 14.5\left(\mathrm{CH}_{3}\right), 20.8\left(\mathrm{CH}_{2}\right), 44.2\left(\mathrm{CH}_{2}\right), 45.2\left(\mathrm{CH}_{2}\right)$, $50.3\left(\mathrm{C}_{\mathrm{q}}\right), 57.2(\mathrm{CH}), 59.7(\mathrm{CH}), 65.1\left(\mathrm{C}_{\mathrm{q}}\right), 116.5\left(\mathrm{CH}_{\mathrm{ar}}\right), 116.7$ (c), $121.5\left(\mathrm{CH}_{\mathrm{ar}}\right), 121.6\left(\mathrm{CH}_{\mathrm{ar}}\right), 122.1\left(\mathrm{CH}_{\mathrm{ar}}\right), 122.5\left(\mathrm{CH}_{\mathrm{ar}}\right)$, $123.8\left(\mathrm{CH}_{\mathrm{ar}}\right), 124.3\left(\mathrm{CH}_{\mathrm{ar}}\right), 124.3\left(\mathrm{CH}_{\mathrm{ar}}\right), 124.9\left(\mathrm{CH}_{\mathrm{ar}}\right), 126.4$ $\left(\mathrm{CH}_{\mathrm{ar}}\right), 126.4\left(\mathrm{CH}_{\mathrm{ar}}\right), 126.6\left(\mathrm{CH}_{\mathrm{ar}}\right), 126.9\left(\mathrm{CH}_{\mathrm{ar}}\right), 130.6\left(\mathrm{CH}_{\mathrm{ar}}\right)$, $130.6\left(\mathrm{CH}_{\mathrm{ar}}\right), 130.8\left(\mathrm{CH}_{\mathrm{ar}}\right), 130.9\left(\mathrm{CH}_{\mathrm{ar}}\right), 131.1\left(\mathrm{C}_{\mathrm{q}}\right), 131.1$ $\left(\mathrm{C}_{\mathrm{q}}\right), 137.6\left(\mathrm{C}_{\mathrm{q}}\right), 137.7\left(\mathrm{C}_{\mathrm{q}}\right), 141.8\left(\mathrm{C}_{\mathrm{q}}\right), 142.0\left(\mathrm{C}_{\mathrm{q}}\right), 149.9\left(\mathrm{C}_{\mathrm{q}}\right)$, $150.8\left(\mathrm{C}_{\mathrm{q}}\right), 181.4(\mathrm{C}=\mathrm{S}), 181.8(\mathrm{C}=\mathrm{S})$, two $\mathrm{C}_{\mathrm{q}}$ signals are overlapped in the aromatic region. $\mathrm{MS}(\mathrm{ESI}): m / z(\%)=803(100)$ $[\mathrm{M}-\mathrm{H}]^{-}$. Anal. Calcd for $\mathrm{C}_{36} \mathrm{H}_{24} \mathrm{~F}_{12} \mathrm{~N}_{4} \mathrm{~S}_{2}$.EtOAc (892.8): $\mathrm{C}$, 53.81; H, 3.61; N, 6.28; S, 7.18. Found: C, 54.03; H, 3.28; N, 6.32; S, 7.09.

Preparation of the tetrabutylammonium salts of chiral acids: The tetrabutylammonium salts of the chiral carboxylates SMD, RMD, RTZ, and SCP were prepared by the neutralization of the corresponding chiral acids with tetrabutylammonium hydroxide (1.0 M in $\mathrm{MeOH})$ [56]. The resulting salts were used as $0.1 \mathrm{M}$ stock solutions in acetone.

The tetrabutylammonium salt of (S)-camphor-10-sulfonate SCS was prepared according to the literature procedure [57], and used as $0.1 \mathrm{M}$ stock solution in the respective solvent required for the experiment.
Photoreaction of dibenzobarrelene derivatives $1 \mathrm{~h}$ and $1 \mathrm{i}$ in the presence of chiral anions: The dibenzobarrelene derivatives $1 \mathbf{h}$ or $\mathbf{1 i}(50 \mu \mathrm{mol})$ were dissolved in a stock solution ( $0.55 \mathrm{~mL}$ of $0.1 \mathrm{M}$ stock solution, $55 \mu \mathrm{mol}, 1.1$ equiv) of the chiral tetrabutylammonium salt, and the solvent was removed in vacuo. The resulting residue was re-dissolved in the solvent of choice $(200 \mathrm{~mL})$. Argon gas was bubbled through the solution for $20 \mathrm{~min}$ to remove residual oxygen from the solvent. The reaction container (DURAN, $\lambda>310 \mathrm{~nm}$ ) was placed ca. $15 \mathrm{~cm}$ in front of the light source, and the solution was irradiated for 3-4 h (TLC control). The solvent was removed in vacuo and the major photoproduct purified by column chromatography $\left(\mathrm{SiO}_{2}\right.$; hexane:acetone: ethyl acetate $=4: 1: 1, \mathrm{v} / \mathrm{v} / \mathrm{v}$ ). The photoproduct was analyzed by ${ }^{1} \mathrm{H}$ NMR spectroscopy in the presence of 5 equiv of tetrabutylammonium SMD as chiral shift reagent. The enantiomeric ratio of the semibullvalene mixture was determined by the integration of the aromatic proton signals from each isomer ( $\delta$ in the range of $8.4-8.7 \mathrm{ppm}$ ), and by the integration of the $\mathrm{NH}$ and cyclopropane $\mathrm{CH}$ signals. Each spectroscopic measurement was repeated twice to ensure the reproducibility.

\section{Supporting Information}

${ }^{1} \mathrm{H}$ NMR and ${ }^{13} \mathrm{C}$ NMR spectra of compounds $\mathbf{1 e}-\mathbf{i}$ and $\mathbf{2 h}-\mathbf{i} ;{ }^{1} \mathrm{H}$ NMR spectra of $\mathbf{2 h}$ with $(S)$-mandelate (SMD) at different molar ratios and corresponding Job plot; ${ }^{1} \mathrm{H}$ NMR spectra of $\mathbf{2 h}$ with $(S)$-mandelate (SMD) as chiral shift reagent.

\section{Supporting Information File 1}

Supporting Information for: Effects of anion complexation on the photoreactivity of bisureido- and bisthioureido-substituted dibenzobarrelene derivatives.

[http://www.beilstein-journals.org/bjoc/content/ supplementary/1860-5397-7-37-S1.pdf]

\section{Acknowledgements}

We thank the Deutsche Akademische Austauschdienst for a fellowship to Dr. Jia Luo (DAAD-Abschluss-Stipendium), and Ms. Stephanie Müller and Dr. Maoqun Tian, University of Siegen, for assistance during the preparation of this manuscript.

\section{References}

1. Svboda, J.; König, B. Chem. Rev. 2006, 106, 5413-5430. doi:10.1021/cr050568w

2. Wessig, P. Angew. Chem., Int. Ed. 2006, 45, 2168-2171. doi:10.1002/anie.200503908 
3. Müller, C.; Bach, T. Aust. J. Chem. 2008, 61, 557-564. doi:10.1071/CH08195

4. Bach, T.; Bergmann, H.; Harms, K. Angew. Chem., Int. Ed. 2000, 39, 2302-2304. doi:10.1002/1521-3773(20000703)39:13<2302::AID-ANIE2302>3.0.CO ;2-6

5. Bach, T.; Bergmann, H.; Harms, K. Org. Lett. 2001, 3, 601-603. doi:10.1021/ol007004t

6. Bach, T.; Aechtner, T.; Neumüller, B. Chem.-Eur. J. 2002, 8, 2464-2475. doi:10.1002/1521-3765(20020603)8:11<2464::AID-CHEM2464>3.0.C O;2-S

7. Bach, T.; Grosch, B.; Strassner, T.; Herdtweck, E. J. Org. Chem. 2003, 68, 1107-1116. doi:10.1021/jo026602d

8. Liu, R. S. H.; Hammond, G. S. Acc. Chem. Res. 2005, 38, 396-403. doi:10.1021/ar040246z

9. Inoue, Y.; Ramamurthy, V., Eds. Chiral Photochemistry; Marcel Dekker: New York, 2004.

10. Ramamurthy, V., Ed. Photochemistry in Organized and Constrained Media, 1st ed.; Wiley-VCH: Weinheim, 1991.

11. Pemberton, B. C.; Barooah, N.; Srivatsava, D. K.; Sivaguru, J. Chem. Commun. 2010, 46, 225-227. doi:10.1039/b920605a

12. Maddipatla, M. V. S. N.; Kaanumalle, L. S.; Natarajan, A.; Pattabiraman, M.; Ramamurthy, V. Langmuir 2007, 23, 7545-7554. doi:10.1021/la700803k

13. Wang, R.; Yuan, L.; Macartney, D. H. J. Org. Chem. 2006, 71 , 1237-1239. doi:10.1021/jo052136r

14. Wu, X.-L.; Luo, L.; Lei, L.; Liao, G.-H.; Wu, L.-Z.; Tung, C.-H. J. Org. Chem. 2008, 73, 491-494. doi:10.1021/jo701998e

15. Yang, C.; Mori, T.; Origane, Y.; Ko, Y. H.; Selvapalam, N.; Kim, K.; Inoue, Y. J. Am. Chem. Soc. 2008, 130, 8574-8575. doi:10.1021/ja8032923

16. Karthikeyan, S.; Ramamurthy, V. Tetrahedron Lett. 2005, 46, 4495-4498. doi:10.1016/j.tetlet.2005.04.115

17. Yoshizawa, M.; Klosterman, J. K.; Fujita, M. Angew. Chem., Int. Ed. 2009, 48, 3418-3438. doi:10.1002/anie.200805340

18. Ishida, Y.; Kai, Y.; Kato, S.-Y.; Misawa, A.; Amano, S.; Matsuoka, Y.; Saigo, K. Angew. Chem. 2008, 120, 8365-8369. doi:10.1002/ange.200803242

19. Tanaka, K.; Toda, F. Chem. Rev. 2000, 100, 1025-1074. doi:10.1021/cr940089p

20. Braga, D.; Grepioni, F. Angew. Chem. 2004, 116, 4092-4102. doi:10.1002/ange.200301721

21. Matsumoto, A. Top. Curr. Chem. 2005, 254, 263-305. doi:10.1007/b10100

22. Scheffer, J. R. Can. J. Chem. 2001, 79, 349-357. doi:10.1139/cjc-79-4-349

23. Ihmels, H.; Scheffer, J. R. Tetrahedron 1999, 55, 885-907. doi:10.1016/S0040-4020(98)01019-9

24. Ke, C.; Yang, C.; Liang, W.; Mori, T.; Liu, Y.; Inoue, Y. New J. Chem. 2010, 34, 1323-1329. doi:10.1039/c0nj00131g

25. Yang, C.; Ke, C.; Fujita, K.; Yuan, D.-Q.; Mori, T.; Inoue, Y. Aust. J. Chem. 2008, 61, 565-568. doi:10.1071/CH08143

26. Lu, R.; Yang, C.; Cao, Y.; Wang, Z.; Wada, T.; Jiao, W.; Mori, T.; Inoue, Y. Chem. Commun. 2008, 374-376. doi:10.1039/b714300a

27. Zimmerman, H. E.; Armesto, D. Chem. Rev. 1996, 96, 3065-3112. doi:10.1021/cr910109c
28. Armesto, C.; Ortiz, M. J.; Agarrabeitia, A. R. Di-m-Methane Rearrangement. In Synthetic Organic Photochemistry; Griesbeck, A.; Mattay, J., Eds.; Molecular and Supramolecular Photochemistry, Vol. 12; Marcel Dekker: New York, 2005; pp 161-181.

29. Zimmerman, H. E.; Sulzbach, H. M.; Tollefson, M. B. J. Am. Chem. Soc. 1993, 115, 6548-6556. doi:10.1021/ja00068a011

30. Scheffer, J. R.; Yang, J. The Photochemistry of Dibenzobarrelene (9,10-Ethenoanthracene) and Its Derivatives. In CRC Handbook of Organic Photochemistry and Photobiology, 1st ed.; Horspool, W. M.; Song, P.-S., Eds.; CRC Press: New York, 1995; pp 204-221.

31. Benitez, M.; Bringmann, G.; Dreyer, M.; Garcia, H.; Ihmels, H.; Waidelich, M.; Wissel, K. J. Org. Chem. 2005, 70, 2315-2321. doi:10.1021/jo047878j

32. Ding, J.; Desikan, V.; Han, X.; Xiao, T. L.; Ding, R. F.; Jenks, W. S.; Armstrong, D. W. Org. Lett. 2005, 7, 335-337. doi:10.1021/ol047599i

33. Evans, S. V.; Garcia-Garibay, M.; Omkaram, N.; Scheffer, J. R.; Trotter, J.; Wireko, F. J. Am. Chem. Soc. 1986, 108, 5648-5650. doi:10.1021/ja00278a060

34. Gamlin, J. N.; Jones, R.; Leibovitch, M.; Patrick, B.; Scheffer, J. R.; Trotter, J. Acc. Chem. Res. 1996, 29, 203-209. doi:10.1021/ar950165q

35. Gudmundsdottir, A. D.; Scheffer, J. R. Tetrahedron Lett. 1990, 31 , 6807-6810. doi:10.1016/S0040-4039(00)97177-6

36. Garcia-Garibay, M.; Scheffer, J. R.; Trotter, J.; Wireko, F. J. Am. Chem. Soc. 1989, 111, 4985-4986. doi:10.1021/ja00195a066

37. Chen, J.; Garcia-Garibay, M.; Scheffer, J. R. Tetrahedron Lett. 1989, 30, 6125-6128. doi:10.1016/S0040-4039(01)93321-0

38. Amendola, V.; Esteban-Gómez, D.; Fabbrizzi, L.; Licchelli, M. Acc. Chem. Res. 2006, 39, 343-353. doi:10.1021/ar050195I

39. Amendola, V.; Fabbrizzi, L.; Mosca, L. Chem. Soc. Rev. 2010, 39, 3889-3915. doi:10.1039/b822552b

40. Etzenbach-Effers, K.; Berkessel, A. Top. Curr. Chem. 2010, 291, 1-27. doi:10.1007/128_2009_3

41. Grondal, C.; Jeanty, M.; Enders, D. Nat. Chem. 2010, 2, 167-178. doi:10.1038/nchem.539

42. Takemoto, Y. Org. Biomol. Chem. 2005, 3, 4299-4306. doi:10.1039/b511216h

43. Connon, S. J. Chem.-Eur. J. 2006, 12, 5418-5427. doi:10.1002/chem.200501076

44. Zhang, Z.; Schreiner, P. R. Chem. Soc. Rev. 2009, 38, 1187-1198. doi:10.1039/b801793j

45. Scheffer, J. R.; Ihmels, H. Liebigs Ann./Recl. 1997, 1925-1929. doi:10.1002/jlac.199719970919

46. Li, A.-F.; Wang, J.-H.; Wang, F.; Jiang, Y.-B. Chem. Soc. Rev. 2010, 39, 3729-3745. doi:10.1039/b926160p

47. Del Giacco, T.; Carlotti, B.; De Solis, S.; Barbafina, A.; Elisei, F. Phys. Chem. Chem. Phys. 2010, 12, 8062-8070. doi:10.1039/b927442a

48. Gray, D.; Philips, D. J. Chem. Phys. 1973, 58, 3216-3220. doi:10.1063/1.1679644

49. Maciejewski, A.; Steer, R. P. Chem. Rev. 1999, 93, 67-98. doi:10.1021/cr00017a005

50. Ramesh, V.; Ramnath, N.; Ramamurthy, V. J. Photochem. 1983, 23 , 141-148. doi:10.1016/0047-2670(83)80056-2

51. Zhao, G.-J.; Han, K.-L. ChemPhysChem 2008, 9, 1842-1846. doi:10.1002/cphc.200800371

52. Hamann, B. C.; Branda, N. R.; Rebek, J., Jr. Tetrahedron Lett. 1993, 34, 6837-6840. doi:10.1016/S0040-4039(00)91808-2

53. Formica, M.; Fusi, V.; Macedi, E.; Paoli, P.; Piersanti, G.; Rossi, P.; Zappia, G.; Orlando, P. New J. Chem. 2008, 32, 1204-1214. doi:10.1039/b719342d 
54. Gale, P. Acc. Chem. Res. 2006, 39, 465-475. doi:10.1021/ar040237q 55. Brooks, S. J.; Edwards, P. R.; Gale, P. A.; Light, M. E. New J. Chem. 2006, 65-70. doi:10.1039/b511963d

56. Kawamura, K.; Nagano, H.; Okuwaki, A. Sep. Sci. Technol. 2005, 40, 2761-2771. doi:10.1080/01496390500326503

57. Olszewska, T.; Gdaniec, M.; Polonski, T. J. Org. Chem. 2008, 73, 4859-4864. doi:10.1021/j08004809

\section{License and Terms}

This is an Open Access article under the terms of the Creative Commons Attribution License

(http://creativecommons.org/licenses/by/2.0), which permits unrestricted use, distribution, and reproduction in any medium, provided the original work is properly cited.

The license is subject to the Beilstein Journal of Organic Chemistry terms and conditions:

(http://www.beilstein-journals.org/bjoc)

The definitive version of this article is the electronic one which can be found at: doi:10.3762/bjoc. 7.37 